\title{
Effects of propoxur on male fertility in wistar rat exposed neonatally
}

\author{
Augustave Kenfack $^{1}{ }^{*}$, Ferdinand Ngoula $^{1}$,Judith K. Chombong ${ }^{1}$, Narcisse B. Vemo ${ }^{1}$, \\ Julius A. Ndukum ${ }^{3}$, Omer B. Ngouateu ${ }^{2}$, Guylène MZ. Zeukeng ${ }^{1}$, \\ Astride MM. Tsambou ${ }^{1}$, Tah Patience Nain ${ }^{1}$, Jemima AN. Guiekep ${ }^{1}$, \\ Baizina Mama ${ }^{4}$, Joseph Tchoumboué ${ }^{1}$, Pierre Kamtchouing ${ }^{2}$
}

\footnotetext{
${ }^{1}$ Department of Animal Sciences, Faculty of Agronomy and Agricultural Sciences, Laboratory of Animal Physiology, University of Dschang, Po Box 188 Dschang-Cameroon

${ }^{2}$ Department of Animal Biology and Physiology, Faculty of Sciences, Laboratory of Animal Physiology, University of Yaoundé I, Yaoundé-Cameroun

${ }^{3}$ School of Veterinary Medicine, University of Ngaoundéré, Ngaoundéré-Cameroon

${ }^{4}$ Chad Republic
}

Received: 15 August 2014

Accepted: 17 September 2014

\section{*Correspondence:}

Dr. Augustave Kenfack,

E-mail: augustavekenfack@yahoo.fr

Copyright: () the author(s), publisher and licensee Medip Academy. This is an open-access article distributed under the terms of the Creative Commons Attribution Non-Commercial License, which permits unrestricted non-commercial use, distribution, and reproduction in any medium, provided the original work is properly cited.

\begin{abstract}
Background: Propoxur is a carbamate pesticide widely used in crop and foodstuff protection. They are known to cause a wide variety of symptoms in animals.

Methods: Twenty four young male rats were exposed to $0.00,1.73,2.60$ and $5.20 \mathrm{mg} / \mathrm{kg}$ body weight through oral intubation for 90 days.

Results: The testis weight increased significantly $(\mathrm{P}<0.05)$ in propoxur-treated animals when compared to the control. The epididymal sperm counts increased not significantly $(\mathrm{P}>0.05)$ but the percentage of sperm motility decreased significantly $(\mathrm{P}<0.05)$ in propoxur-gavaged males. Histopathological examination revealed the disorganisation of seminiferous epithelia with the loss of germ cells in some gavaged rats. The fertility rate did not vary dose dependently and no significant $(\mathrm{P}>0.05)$ change was observed between the control and treated males for the litter size, viability rate and sex-ratio.

Conclusions: Despite the impairment of seminal epithelia and sperm characteristics, male rats orally exposed to the studied doses of propoxur maintained their fertility at the $90^{\text {th }}$ day of treatment.
\end{abstract}

Keywords: Propoxur, Reproductive organs, Cauda epididymis counts, Cauda epididymis sperm motility, Fertility

\section{INTRODUCTION}

Carbamates are a group of pesticides including insecticides, herbicides, acaricide, nematicide and fungicides. ${ }^{1-3}$

They cause a wide variety of symptoms in mammals by inhibiting the enzyme acetylcholinesterase. ${ }^{4,5}$ This inhibition leads to the accumulation of acetylcholine and then the hyperactivity of sympathetic and parasympathetic nervous systems. ${ }^{3,6-9,10}$ Studies on chronic exposure to carbamate pesticides reported several effects of unknown origin and suggested that additional mechanisms distinct from acetylcholinesterase are involved. ${ }^{3,11}$ Many biological functions controlled by the autonomous nervous systems are susceptible to be impaired. ${ }^{2,12,13}$

Propoxur is one of the most important carbamate insecticides. It is used on a variety of insect pests such as chewing and sucking insects, ants, cockroaches, crickets, flies and mosquitoes and may be in control of these in 
agricultural or in non-agricultural applications. ${ }^{14}$ For the agriculture, it is manufactured to protect cane, cocoa, fruit, grapes, maize, vegetables, rice, cotton, lucerne, forestry and ornamentals. Propoxur is available in several types of formulations including emulsifiable concentrates, wettable powders, baits, aerosol, fumigants and granules. In Cameroon, the formulation commercially named unden is widely used, probably due to its low cost.

Propoxur is a highly toxic compound via the oral route. ${ }^{14}$ Its admissible daily dose (dose that can be taken daily by a man of $60 \mathrm{~kg}$ throughout the life without any effects) is $0.02 \mathrm{mg} / \mathrm{kg}^{5}$. Applicators who used propoxur regularly showed a pronounced daily fall in whole blood cholinesterase activity. ${ }^{14}$ The administration of $18 \mathrm{mg} / \mathrm{kg}$ of propoxur resulted to the fall of growth in the mice. ${ }^{5}$ In female rats given high dietary doses of approximately 18 $\mathrm{mg} / \mathrm{kg} /$ day of propoxur, reduced lactation and litter size were observed. ${ }^{15}$ According to the same author, at 25 $\mathrm{mg} / \mathrm{kg} /$ day administered to pregnant rats, there was a decrease in the number of offspring. Dietary doses of approximately $2.25 \mathrm{mg} / \mathrm{kg}$ did not affect fertility, litter size and lactation. In the present study, we led an investigation in order to evaluate the effect of oral administration of this pesticide on some male reproductive parameters in rats exposed early after the birth.

\section{METHODS}

\section{Animals}

Twenty four male wistar rats of 30 days old and 28 to 32 g of body weight at the start of the essay, and 48 females aged 4 months were produced in animal physiology laboratory of Dschang University/faculty of agronomy and agricultural sciences. Rats were housed in the glass cages at room temperature and 12h-day light/dark cycle, with free access to feed and vitamin-enriched water. The animals used in this study were treated according to ethical principles in animal research.

\section{Pesticide}

The propoxur used is a powder commercially named unden $75 \mathrm{Ew}$ and was produced by Bayer. The studied doses were $0.00 ; 1.73$; and $5.20 \mathrm{mg} / \mathrm{kg}$ body weight.

\section{Essay}

The young male rats were distributed into 4 groups of 6 animals. To each group was attributed randomly an experimental dose of propoxur or distilled water. 0.583 $\mathrm{ml}$ of distilled water or solution containing propoxur was administered per kilogramme body weight. Males were gavaged daily from post-natal days 30 to 120 and volumes of gavage solution adjusted weekly to body weight. At the end of the treatment period, they were killed by chloroform overdose. Prior to sacrifice, each male was mated to 2 females during 15 days.

\section{Data collection}

Body weight was measured at the end of exposure. The abdomen was then opened and the testes, epididymis, vas deferent, seminal vesicle and prostate were removed and weighed.

The right cauda epididymis was weighed and minced in a known volume of $0.9 \% \mathrm{NaCl}$ solution $\left(36^{\circ} \mathrm{C}\right)$ for sperm motility and concentration evaluation. The motile and non-motile sperms were counted separately in many light microscopic areas. The sperm concentration was obtained using the Thomas haematocytometer.

The testis was fixed in Bouin's fluid, and then washed, dehydrated in alcohol bath of ascending grade, clarified in xylene immersion, embedded in paraffin, sectioned at $5 \mu \mathrm{m}$ and stained with haematoxylin and eosin. The tissue sections were observed under a light microscope (400x) for qualitative and quantitative changes in the seminiferous tubules and intertubular space.

Fertility rate was calculated on the basis of the number of males which procreate per lot. Litter was examined for size, viability and sex-ratio.

\section{Statistical analysis}

Data were expressed in mean \pm SEM. Statistical analysis was done by ANOVA and Duncan test at $5 \%$.

\section{RESULTS}

\section{Reproductive organs weight}

The testis weight (Table 1) was higher in propoxurtreated rats as compared to the control, with a significant ( $\mathrm{P}<0.05)$ difference in $2.60 \mathrm{mg} / \mathrm{kg}$-gavaged animals. The weights of the epididymis, vas deferent, seminal vesicles and prostate were very closed among treatments.

\section{Cauda epididymal sperm concentration and mobility}

The epididymal sperm counts (Table 2) were comparables $(\mathrm{P}>0.05)$ among dose groups. On the other hand, the percentage of motile spermatozoa decreased significantly $(\mathrm{P}<0.05)$ in 1.73 -and $5.20 \mathrm{mg} / \mathrm{kg}$-treated rats when compared to the control group.

\section{Male reproductive performances}

Fertility rate was significantly $(\mathrm{P}<0.05)$ the highest in male rats receiving $1.73 \mathrm{mg} / \mathrm{kg}$, followed by the 5.20 $\mathrm{mg} / \mathrm{kg}$ treated group and the control. No significant $(\mathrm{P}$ $>0.05)$ difference was observed between control and gavaged animals for the litter size, viability rate and sex ratio (Table 3 ). 
Table 1: Effects of propoxur on the male reproductive organs weight in rat.

\begin{tabular}{|l|llll|}
\hline Organs & $\begin{array}{l}\text { Doses }\left(\mathrm{mg}^{\mathrm{k}} \mathrm{kg}^{-1} \mathrm{day}^{-1}\right) \\
\mathbf{0 . 0 0}(\mathbf{c o n t r o l}) \\
(\mathbf{n = 6})\end{array}$ & $\begin{array}{l}\mathbf{1 . 7 3} \\
(\mathbf{n = 6})\end{array}$ & $\begin{array}{l}\mathbf{2 . 6 0} \\
(\mathbf{n = 6})\end{array}$ & $\begin{array}{l}\mathbf{5 . 2 0} \\
(\mathbf{n = 6})\end{array}$ \\
\hline Testis & $0.27 \pm 0.06^{\mathrm{a}}$ & $0.31 \pm 0.02^{\mathrm{ab}}$ & $0.39 \pm 0.11^{\mathrm{b}}$ & $0.32 \pm 0.59^{\mathrm{ab}}$ \\
\hline Epididymis & $0.12 \pm 0.01^{\mathrm{a}}$ & $0.12 \pm 0.02^{\mathrm{a}}$ & $0.12 \pm 0.02^{\mathrm{a}}$ & $0.12 \pm 0.01^{\mathrm{a}}$ \\
\hline Vas deferent & $0.04 \pm 0.00^{\mathrm{a}}$ & $0.05 \pm 0.01^{\mathrm{a}}$ & $0.04 \pm 0.00^{\mathrm{a}}$ & $0.04 \pm 0.01^{\mathrm{a}}$ \\
\hline Seminal vesicle & $0.31 \pm 0.09^{\mathrm{a}}$ & $0.33 \pm 0.07^{\mathrm{a}}$ & $0.26 \pm 0.09^{\mathrm{a}}$ & $0.32 \pm 0.07^{\mathrm{a}}$ \\
\hline Prostate & $0.09 \pm 0.01^{\mathrm{a}}$ & $0.09 \pm 0.02^{\mathrm{a}}$ & $0.08 \pm 0.02^{\mathrm{a}}$ & $0.08 \pm 0.01^{\mathrm{a}}$ \\
\hline
\end{tabular}

a,b: Within the same line, numbers with the same letters are not significantly $(\mathrm{P}>0.05)$ different $\mathrm{n}$ : Number of observations

Table 2: Influence of propoxur on the cauda epididymal sperm concentration and motility.

\begin{tabular}{|lllll|}
\hline $\begin{array}{l}\text { Cauda epididymal } \\
\text { sperm characteristics }\end{array}$ & $\begin{array}{l}\text { Doses }\left(\mathrm{mg}_{\mathrm{kg}}{ }^{-1} \mathrm{day}^{-1}\right) \\
(\mathbf{n = 6})\end{array}$ & $\begin{array}{l}\mathbf{1 . 7 3} \\
(\mathbf{n = 6})\end{array}$ & $\begin{array}{l}\mathbf{2 . 6 0} \\
(\mathbf{n = 6})\end{array}$ & $\begin{array}{l}\mathbf{5 . 2 0} \\
(\mathbf{n}=\mathbf{6})\end{array}$ \\
\hline Number/cauda $\left(\mathrm{x} 10^{6}\right)$ & $7.51 \pm 5.97^{\mathrm{a}}$ & $4.25 \pm 3.29^{\mathrm{a}}$ & $9.56 \pm 6.16^{\mathrm{a}}$ & $8.64 \pm 4.11^{\mathrm{a}}$ \\
\hline Number/gram $\left(\mathrm{x} 10^{6}\right)$ & $54.67 \pm 37.36^{\mathrm{a}}$ & $35.65 \pm 28.90^{\mathrm{a}}$ & $75.72 \pm 43.69^{\mathrm{a}}$ & $81.25 \pm 33.22^{\mathrm{a}}$ \\
\hline Motility $(\%)$ & $64.19 \pm 9.10^{\mathrm{a}}$ & $43.99 \pm 4.21^{\mathrm{b}}$ & $57.04 \pm 7.22^{\mathrm{a}}$ & $44.09 \pm 12.37^{\mathrm{b}}$ \\
\hline
\end{tabular}

a,b: Within the same line, numbers with the same letters are not significantly $(\mathrm{P}>0.05)$ different $\mathrm{n}$ : Number of observations

Table 3: Influence of propoxur on the reproductive performances in rats.

\begin{tabular}{|lllll|}
\hline Parameters & $\begin{array}{l}\text { Doses }\left(\text { mg.kg }^{-1} \text { day }^{-1}\right) \\
\text { 0.00 }(\text { control) } \\
(\mathbf{n = 6})\end{array}$ & $\begin{array}{l}\mathbf{1 . 7 3} \\
(\mathbf{n = 6})\end{array}$ & $\begin{array}{l}\mathbf{2 . 6 0} \\
(\mathbf{n = 6})\end{array}$ & $\begin{array}{l}\mathbf{5 . 2 0} \\
(\mathbf{n = 6})\end{array}$ \\
\hline Fertility rate & $0.33 \pm 0.52^{\mathrm{ab}}$ & $1.00 \pm 0.00^{\mathrm{c}}$ & $0.20 \pm 0.45^{\mathrm{a}}$ & $0.83 \pm 0.41^{\mathrm{bc}}$ \\
\hline Litter size & $6.50 \pm 0.71^{\mathrm{a}}$ & $6.50 \pm 3.70^{\mathrm{a}}$ & $6.00 \pm 1.00^{\mathrm{a}}$ & $4.67 \pm 3.21^{\mathrm{a}}$ \\
\hline Viability rate $(\%)$ & $92.86 \pm 10.11^{\mathrm{a}}$ & $72.73 \pm 48.67^{\mathrm{a}}$ & $100.00 \pm 0.00^{\mathrm{a}}$ & $100.00 \pm 0.00^{\mathrm{a}}$ \\
\hline Sex-ratio & $61.90 \pm 6.73^{\mathrm{ab}}$ & $50.12 \pm 11.96^{\mathrm{ab}}$ & $83.33 \pm 2.01^{\mathrm{b}}$ & $35.71 \pm 31.13^{\mathrm{a}}$ \\
\hline
\end{tabular}

a,b: Within the same line, numbers with the same letters are not significantly $(\mathrm{P}>0.05)$ different $\mathrm{n}$ : Number of observations
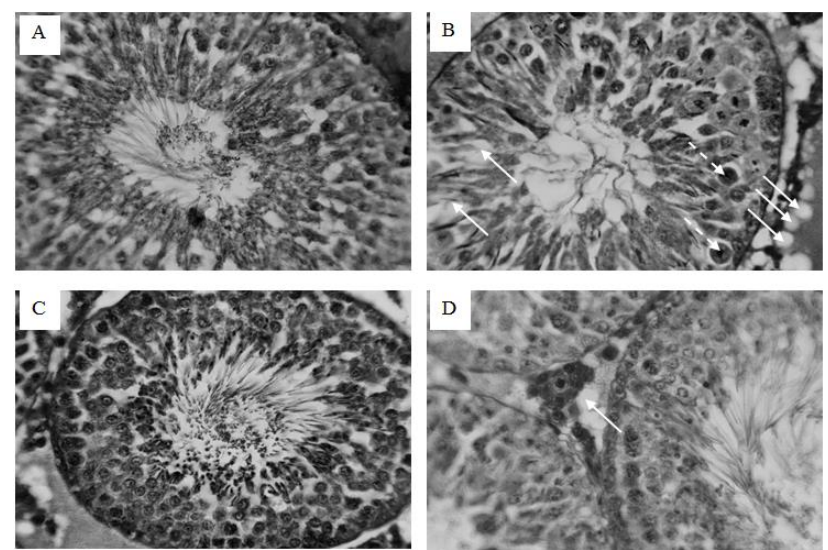

Figure 1: Testis histological sections of rat at $90^{\text {th }}$ day of exposure to propoxur.

A: control; B: rats gavaged with $1.73 \mathrm{mg} / \mathrm{kg}$; C: rats treated with $2.60 \mathrm{mg} / \mathrm{kg}$; D: rats treated with $5.20 \mathrm{mg} / \mathrm{kg}$ body weight. Note the integrity of tubules in control (A) and highest dose groups (C, D), the presence of vacuoles (whole arrow) and degenerating germ cells (interrupted arrow) in the lowest dose-gavaged rats (B).

Magnification: $400 \mathrm{x}$ 


\section{Histopathology}

The testis histological sections (Figure 1) reveal the existence of degenerating germ cells and vacuoles in the epithelia of a few numbers of seminiferous tubules and in intertubular spaces in propoxur-treated rats (picture B). The variation of the pathologies degree was not dose dependant; most of the seminiferous tubules were not affected even in the highest dose groups (picture $\mathrm{C}$ and D).

\section{DISCUSSION}

The increase of testes weight in propoxur-treated males is the contrary of a previous result showing no significant change after 90 days of gavage with $100 \mathrm{mg} / \mathrm{kg}$ of carbaryl, a carbamate pesticide. ${ }^{16}$ The increase of the testis weight observed in the present study could be attributed to food consumption since a parallelism has been observed between both parameters. Indeed, it is reported that mammals insufficiently fed during prepubertal period do not present well developed gonads at adulthood. ${ }^{17}$

As the functioning of the accessory sex organs is under the control of the gonads, ${ }^{17}$ it is not clear why the weight of epididymis, vas deferent, seminal vesicles and prostate remained unchanged with increasing dose of propoxur while the testis weight increased. An identical result has been obtained by treating prepubertal rats with up to 10.50 mg. $\mathrm{kg}^{-1}$ chlorpiryphos-ethyl. ${ }^{18}$ The oral administration of $100 \mathrm{mg} / \mathrm{kg}$ carbaryl also resulted in comparability of the weight of these glands. ${ }^{16}$ However, the weight of the accessory sex glands decreased significantly in rats gavaged with a dose of carbofuran (carbamate) as small as $0.8 \mathrm{mg} / \mathrm{kg}$ body weight. ${ }^{19}$

The disorganisation of the seminal epithelium, the presence of a great rate of vacuoles at ad-luminal location and the position of necrosing germ cells indicate that there has had loss of germ cells and that the loss of those cells begins with precocious spermiation, before progressively affects less differentiated cell types.

Sperm count remained unchanged and sperm motility rate lowered with increasing dose of propoxur. Other carbamate pesticides such as carbofuran and carbaryl orally administered to rats led to a decline in epidymal sperm count and percentage of sperm motility. ${ }^{16,19,20}$ The statistical comparability of the cauda epididymal sperm count in the present study was foreseeable given that no dose related significant difference was noted for the epididymal weight. Also, according to an author, the weight of the epididymis could be related to its sperm content. $^{21}$

The decline of sperm motility percentage in propoxurtreated rats is imputable to the cytotoxic effect of propoxur and precocious spermiation as evidenced by the presence of vacuoles and degenerating germ cells in the epithelia of seminiferous tubules.
The lack of significant difference among mortality rates could be attributed to the similarity of the litter size in different dose groups.

\section{CONCLUSION}

Propoxur impaired the seminal epithelia and sperm characteristics. However, despite those effects, male rats orally exposed to the studied doses maintained their fertility at the $90^{\text {th }}$ day of treatment.

\section{Funding: No funding sources}

Conflict of interest: None declared

Ethical approval: The study was approved by the institutional animal ethics committee

\section{REFERENCES}

1. Sanil D, Shetty NJ. Genetic study of propoxur resistance-A Carbamate Insecticide in the malaria mosquito anopheles stephensi Liston. Malaria Res Treat. 2010;2010:502824.

2. Shanthalatha A, Madhuranath BN, Yajurvedi HN. Effects of methomyl formulation, a carbamate pesticide on ovarian follicular development and fertility in albino mice. J Environ Biol. 2010;33:337.

3. Smulders CJGM, Van Kleef RGDM, De Groot A, Gotti C, Vijverberg HPM. A non-competitive, sequential mechanism for inhibition of rat $\alpha 4 \beta 2$ neuronal nicotinic acetylcholine receptors by carbamate pesticides. Toxicol Sci. 2004a;82:219-27.

4. Penn State Extension. Fact sheets: Potential health effects of pesticides, 2009. Available at: extension.psu.edu/pests/pesticide.../factsheets/potenti. Accessed August 2014.

5. Van Hammée ML, Wattiez C. Home use pesticide: health hazard. In: Van Hammée ML, Wattiez C, eds. Pesticides Action Network. Belgium: Belgium Press; 1999: 84.

6. Ankarberg E, Fredriksson A, Eriksson P. Increased susceptibility to adult paraoxon exposure in mice neonatally exposed to nicotine. Toxicol Sci. 2004;82:555-61.

7. Cox C. Chlorpyrifos, part 2: Human exposure. J Pestic Reform. 2004;15(1):14-28.

8. Padilla S, Marshall RS, Hunter DL, Hunter DL, Oxendine S, Moser VC, et al. Neurochemical effects of chronic dietary and repeated high-level acute exposure to chlorpyrifos in rats. Toxicol Sci. 2005;88(1):161-71.

9. Richardson JR, Chambers JE. Neurochemical effects of repeated gestational exposure to chlorpyrifos in developing rats. Toxicol Sci. 2004;77:83-90.

10. Smulders CJGM, Bueters TJH, Vailati S, Van Kleef RGDM, Vijverberg HPM. Block of neuronal nicotinic acetylcholine receptors by organophosphate insecticides. Toxicol Sci. 2004b;82:545-54.

11. Moser VC. Comparison of aldicarb and metamidophos neurotoxicity at different ages in rat: 
behavioural and biochemical parameters. Toxicol Appl Pharmacol. 1999;157(2):94-106.

12. Lachenmeier DW, Lima MCP, Nobrega ICC, Pereira JAP, Kerr-Correa F, Kanteres F, et al. Cancer risk assessment of ethyl carbamate in alcoholic beverages from Brazil with special consideration to the spirit cachaça and tiquira. BMC Cancer. 2010;10:266.

13. Saladin KS. WBC. In: Saladin KS, eds. Anatomy and Physiology: the Unity of Form and Function. 3rd ed. Boston, Massachueset, Burrridge, Illinoi. McGraw-Hill; 1998.

14. Extension Toxicology Network. Propoxur, 1996. Available at: http://extoxnet.orst.edu/pips/propoxur.htm.

15. Baron RL. Carbamate insecticides. In: Hayes W. Jr, Laws ER Jr, eds. Handbook of Pesticide Toxicology. 2nd ed. New York: Academic Press; 1991: 3-6.

16. Pant N, Srivastava SC, Prasad AK, Shankar R, Srivastava SP. Effects of carbaryl on the rat's male reproductive system. Vet Hum Toxicol. 1995a;37(5):421-5.

17. Mark McEntee. Gonads. In: Derivaux J, Ectors FO, eds. Reproduction in Domestic Mammals. 1st ed. US: Elsevier, 1986: 401.
18. Kenfack A, Ngoula F, Tchoumboué J, Kamtchouing P. Influence of chlorpiryphos-ethyl on some reproductive parameters in male albinos rat exposed during post natal development. Int J Biol Chem Sci. 2007;1(3):237-43.

19. Pant N, Prasad AK, Srivastava SC, Shankar R, Srivastava SP. Effect of oral administration of carbofuran on male reproductive system of rat. Hum Exp Toxicol. 1995b;14(11):889-94.

20. Pant N, Shankar R, Srivastava SP. In utero and lactational exposure of carbofuran to rats: effects on testis and sperm. Hum Exp Toxicol. 1997;16(5):26772.

21. Klinefelter GR, Srader LF, Suarez JD, Roberts NL. Bromoacetic acid exerts qualitative effects on rat sperm: implication for a novel biomarker. Toxicol Sci. 2002;68:164-73.

DOI: $10.5455 / 2320-1770.1 j r \operatorname{cog} 20141205$

Cite this article as: Kenfack A, Ngoula F, Chombong JK, Vemo NB, Ndukum JA, Ngouateu OB, Zeukeng GMZ, Tsambou AMM, Nain TP, Guiekep JAN, BMama B, Tchoumboué J, Kamtchouing P. Effects of propoxur on male fertility in wistar rat exposed neonatally. Int J Reprod Contracept Obstet Gynecol 2014;3:898-902. 